\title{
KAJIAN LANDING STATION ALAT DETEKSI DINI TSUNAMI BERBASIS KABEL SERAT OPTIK BAWAH LAUT DI KABUPATEN PASANGKAYU, SULAWESI BARAT
}

\section{LANDING STATION STUDY FOR UNDERWATER CABLE-BASED TSUNAMETER FIBER OPTIC IN PASANGKAYU, WEST SULAWESI}

\author{
Puspa Khaerani ${ }^{1}$, Heru Sri Naryanto ${ }^{2}$, Dian Nuraini Melati ${ }^{1}$, Syakira Trisnafiah ${ }^{1}$ \\ ${ }^{1}$ Perekayasa pada Pusat Teknologi Reduksi Risiko Bencana - Badan Pengkajian dan Penerapan \\ Teknologi, Jl. M.H. Thamrin No.8, Jakarta 10340 \\ ${ }^{2}$ Peneliti pada Pusat Teknologi Reduksi Risiko Bencana - Badan Pengkajian dan Penerapan \\ Teknologi, JI. M.H. Thamrin No.8, Jakarta 10340 \\ email: puspa.khaerani@bppt.go.id
}

\begin{abstract}
The construction of an underwater cable-based tsunameter fiber-optic was planned to be installed in the Makassar Strait with a landing point in West Sulawesi. Land infrastructures such as a Power House (PH), a communication tower, and a Beach Manhole (BMH) needed to sustain the system's power in order to survive. Therefore, the aim of this scientific paper was to study several alternative landing station locations in Pasangkayu, West Sulawesi and then determine the priority locations. The methods used to achieve these objectives are field observation methods and secondary data analysis based on parameters of land area conditions, environmental conditions, supporting infrastructure, social conditions and licensing systems, and marine activities. These aspects were then assessed to determine the priority location. The selected location based on the assessment was ALT-02B. In succession, the three priority locations selected from the order of most priority to least priority were ALT-02B, ALT-02A, and ALT-06. These was not necessarily the final choice location which will be used as construction site of a land infrastructure of tsunami early detection system because in the process, there were still things to be considered and aspects that became the main priority in decisions making.
\end{abstract}

Keywords: landing station, cable-based tsunameter, beach manhole, power house, tower communication

\begin{abstract}
ABSTRAK
Pembangunan sistem deteksi dini tsunami berbasis kabel serat optik (Cable-Based Tsunameter/CBT) bawah laut direncanakan akan dipasang di Selat Makassar dengan titik landing di Sulawesi Barat. Infrastruktur darat seperti Power House (PH), tower komunikasi, dan Beach Manhole (BMH) dibutuhkan untuk menopang daya sistem agar dapat bertahan. Maka dari itu, tujuan dari karya ilmiah ini adalah mengkaji beberapa lokasi alternatif landing station di Pasangkayu, Sulawesi Barat untuk kemudian ditentukan prioritas lokasinya. Metode yang digunakan untuk mencapai tujuan tersebut yaitu metode observasi lapangan dan analisis data sekunder berdasarkan parameter kondisi area lahan, kondisi lingkungan, infrastruktur pendukung, kondisi sosial dan sistem perizinan, serta aktivitas laut. Aspek-aspek tersebut kemudian dinilai untuk menentukan prioritas lokasi terpilih. Lokasi terpilih berdasarkan penilaian yang dilakukan adalah ALT-02B. Secara berturut-turut tiga lokasi yang prioritas yang dipilih dari urutan paling prioritas sampai kurang prioritas adalah ALT-02B, ALT-02A, dan ALT06. Lokasi prioritas terpilih ini belum tentu merupakan lokasi pilihan akhir yang digunakan dalam pembangunan infrastruktur darat sistem deteksi dini tsunami karena dalam prosesnya masih ada halhal yang harus dipertimbangkan dan aspek yang dijadikan prioritas utama dalam mengambil keputusan.
\end{abstract}

Kata kunci: landing station, cable-based tsunameter, beach manhole, power house, tower komunikasi 


\section{PENDAHULUAN}

\subsection{Latar Belakang}

Pada tahun 2018 lalu, bencana tsunami dan likuefaksi menghantam Kota PaluDonggala, Sulawesi Tengah. Berdasarkan kejadian tersebut muncul penelitian baru mengenai potensi tsunami di daerah Selat Makassar baik tsunami yang diakibatkan oleh tektonik maupun atypical tsunami (tsunami akibat kejadian tidak biasa atau bukan tektonik) seperti Muhari et al. (2018) dan Nakata et al. (2020). Brackenridge et al. (2019) menjelaskan dua potensi tsunami di Selat Makassar dapat berupa patahan yang umumnya bersumber dari Zona Sesar PaluKoro dan Selat Makassar fault-thrust-belt di sisi barat Sulawesi. Gambaran fault-thrust-belt di perairan pesisir Sulawesi Barat juga menandakan daerah ini aktif secara tektonik serta dikaji potensi tsunami akibat longsoran dari patahan tersebut oleh Bachri (2012). Sedangkan potensi tsunami akibat longsoran diperkirakan berada di bagian selatan cekungan Selat Makassar (Brackenridge et al., 2019).

Karena latar belakang kejadian dan penelitian tersebut, perkembangan sistem deteksi dini tsunami semakin canggih. Saat ini banyak dikembangkan suatu sistem deteksi tsunami yang tidak hanya mendeteksi kejadian tsunami dari gempa bumi tetapi juga dapat mendeteksi tsunami yang berasal dari longsoran bawah laut. Sistem tersebut tentu saja harus berkelanjutan dan dapat memberikan informasi yang berguna bagi masyarakat pesisir seperti yang dikemukakan oleh Bernard dan Titov (2015) dimana produk sistem deteksi dini tsunami harus dapat menghasilkan tiga produk, 1) energi tsunami yang dihasilkan; 2) Peta rendaman tsunami; 3) Peta arus tsunami di pesisir pantai yang terstandarisasi, akurat, dan real-time.

Untuk mencegah atau mengurangi dampak yang timbul karena tsunami, sistem deteksi dini tsunami berbasis kabel merupakan salah satu pilihan yang dapat digunakan. Untuk membangun sistem deteksi dini tersebut, diperlukan suatu area untuk fasilitas di darat berupa Beach Manhole (BMH), Power House $(\mathrm{PH})$, dan tower komunikasi. Fasilitas tersebut terutama $\mathrm{PH}$ dan tower memerlukan area yang aman atau bebas dari ancaman gempa bumi dan tsunami (Pradono, 2020). Maka dari itu, pada artikel ini dibahas mengenai pemilihan lokasi landing station sebagai pendukung fasilitas sistem deteksi dini tsunami.

Secara international, International Cable Protection Committee (ICPC) telah membuat suatu rekomendasi mengenai desktop study sistem kabel laut pada tahun 2018. Salah satu yang dibahas dalam desktop study tersebut adalah penentuan lokasi landing station. Hal ini membuktikan bahwa pemilihan lokasi alternatif landing station untuk sistem deteksi dini tsunami di Kabupaten Pasangkayu penting. Namun, pada kajian lokasi alternatif landing station Pasangkayu dilakukan beberapa modifikasi dari rekomendasi yang dikeluarkan oleh ICPC yang menyesuaikan dengan kebutuhan teknis alat deteksi dini berbasis kabel serat optik bawah laut yang dikembangkan serta regulasi yang berlaku di Indonesia.

\subsection{Kondisi Tsunami di Sulawesi Barat}

Sumber tsunami di Selat Makassar umumnya terjadi karena tektonik karena daerah tersebut merupakan pertemuan tiga lempeng tektonik. Akibat kondisi tektonik tersebut tsunami biasanya terjadi dari gempa bumi yang bersumber di laut atau bisa juga karena longsoran gunung api bawah laut. Secara tektonik, di Sulawesi Barat khususnya di perairan Selat Makassar dipengaruhi oleh sesar mendatar Palu-Koro yang memanjang sampai ke cekungan Selat Makassar bagian utara, sesar naik Selat Makassar Utara, sesar naik Selat Makassar tengah, dan Sesar Mamuju (PUPR, 2017).

Historis kejadian tsunami penting untuk diketahui dikarenakan sistem kabel laut yang digunakan membutuhkan pasokan energi atau daya dari darat. Infrastruktur darat yang dibangun untuk mendukung sistem kabel laut seperti PH dan tower komunikasi harus aman dari ancaman tsunami agar pada saat kejadian tsunami sistem deteksi dini tidak mati dan masih dapat menjalankan fungsinya dengan baik. Beberapa historis kejadian tsunami di Sulawesi Barat yang berasal dari gempa bumi dan longsoran gunung api bawah laut dapat dilihat pada Tabel 1. 
Puspa Khaerani, Heru Sri Naryanto, Dian Nuraini Melati, Syakira Trisnafiah: Kajian Landing Station Alat Deteksi Dini Tsunami Berbasis Kabel Serat Optik Bawah Laut Di Kabupaten Pasangkayu,

Sulawesi Barat

Tabel 1. Riwayat Tsunami Berdasarkan dari data NOAA

\begin{tabular}{|c|c|c|c|c|c|c|c|c|}
\hline No & Tahun & $\begin{array}{c}\text { Bula } \\
n\end{array}$ & $\underset{i}{\operatorname{Har}}$ & Kejadian & Sumber & $\begin{array}{l}\text { Magnitude } \\
\text { Gempa }\end{array}$ & $\begin{array}{c}\text { Maksimum } \\
\text { Gelombang } \\
(\mathrm{m})\end{array}$ & Lokasi \\
\hline 1 & 1860 & 8 & 0 & Sangat Diragukan & Gempa & 0 & 0 & $\begin{array}{l}\text { Sulawesi - N. } \\
\text { Moluccas Island }\end{array}$ \\
\hline 2 & 1871 & 8 & 25 & Sangat Diragukan & Gempa & 0 & 0 & N. Moluccas Island \\
\hline 3 & 1904 & 2 & 2 & Dipertanyakan & $\begin{array}{c}\text { Tidak } \\
\text { Diketahui }\end{array}$ & 0 & 0 & Celebes Sea \\
\hline 4 & 1917 & 3 & 16 & Dipertanyakan & $\begin{array}{c}\text { Tidak } \\
\text { Diketahui }\end{array}$ & 0 & 1.5 & Java Sea \\
\hline 5 & 1920 & 1 & 29 & Sangat Diragukan & Gempa & 0 & 2 & N. Moluccas Island \\
\hline 6 & 1921 & 5 & 14 & Dipertanyakan & Gempa & 6.2 & 1 & Makassar Strait \\
\hline 7 & 1927 & 12 & 1 & Kemungkinan Terjadi & Gempa & 6.3 & 15 & Sulawesi \\
\hline 8 & 1938 & 5 & 19 & Terjadi Tsunami & Gempa & 7.6 & 3 & Makassar Strait \\
\hline 9 & 1939 & 12 & 21 & Kemungkinan Terjadi & Gempa & 8 & 0 & N. Moluccas Island \\
\hline 10 & 1957 & 10 & 26 & Dipertanyakan & Gempa & 6 & 0 & Makassar Strait \\
\hline 11 & 1967 & 4 & 11 & Kemungkinan Terjadi & Gempa & 5.5 & 0 & Makassar Strait \\
\hline 12 & 1968 & 8 & 14 & Terjadi Tsunami & Gempa & 7.8 & 10 & Banda Sea \\
\hline 13 & 1969 & 2 & 23 & Terjadi Tsunami & Gempa & 6.9 & 4 & Makassar Strait \\
\hline 14 & 1984 & 1 & 8 & Sangat Diragukan & Gempa & 6.8 & 0 & Sulawesi \\
\hline 15 & 1996 & 1 & 1 & Terjadi Tsunami & Gempa & 7.9 & 3.43 & Sulawesi \\
\hline 16 & 2000 & 5 & 4 & Terjadi Tsunami & Gempa & 7.6 & 6 & Sulawesi \\
\hline 17 & 2008 & 11 & 16 & Terjadi Tsunami & Gempa & 7.3 & 0.13 & Sulawesi \\
\hline 18 & 2018 & 9 & 28 & Terjadi Tsunami & $\begin{array}{l}\text { Gunung Api } \\
\text { \& Longsoran }\end{array}$ & 7.5 & 10.73 & Sulawesi \\
\hline
\end{tabular}

Sumber: NOAA National Centers for Environmental Information

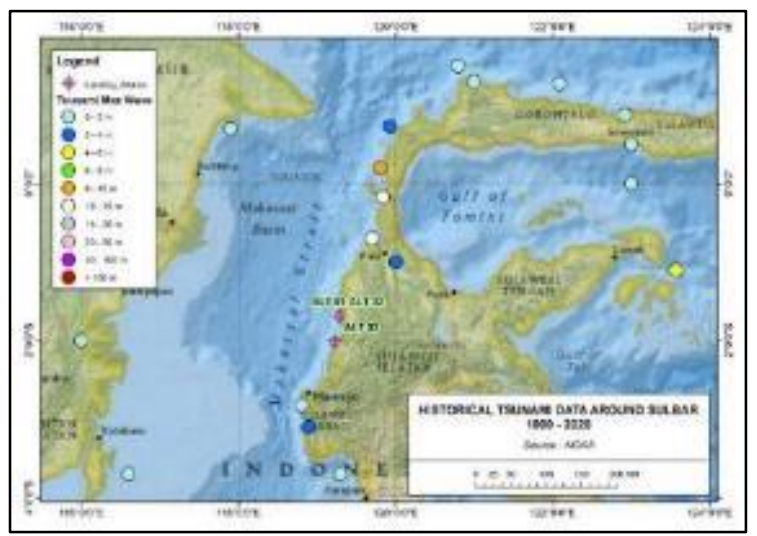

Gambar 1. Riwayat Tsunami di Sekitar Lokasi Kegiatan (Sumber: NOAA National Centers for Environmental Information)

\subsection{Maksud dan Tujuan}

Pendaratan kabel laut sistem deteksi dini tsunami berada di Kabupaten Pasangkayu, Provinsi Sulawesi Barat. Tujuan dari dari kegiatan ini adalah untuk mendapatkan prioritas alternatif lokasi landing station yang berupa $\mathrm{BMH}, \mathrm{PH}$, dan tower di Kabupaten Pasangkayu yang nanti akan digunakan untuk pembangunan sistem peringatan dini tsunami berbasis kabel serat optik bawah laut (Indonesia Cable-Based Tsunameter/InaCBT).

\section{BAHAN DAN METODE}

\subsection{Bahan}

\subsubsection{Landing Station (LS)}

Komponen lahan yang perlu ditinjau secara langsung di lapangan adalah sebagai berikut:

a. Landing Point (LP)

LP merupakan titik ikat dimana tempat bertemunya antara kabel darat dengan kabel yang berasal dari laut. Posisi LP ini dapat ditiadakan apabila rencana lokasi $\mathrm{BMH}$ berada di dekat garis pantai.

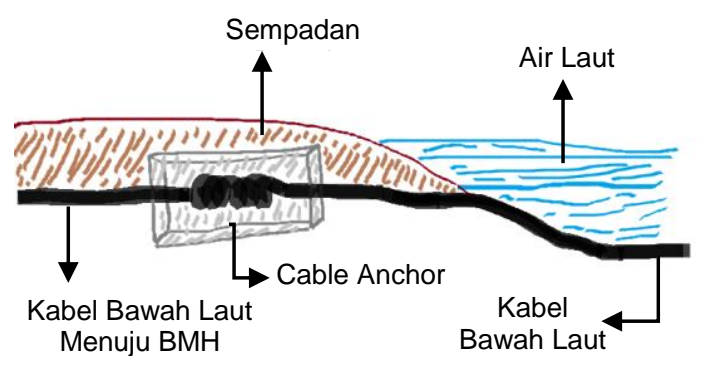

Gambar 2. Ilustrasi LP Tempat

Mendaratnya Kabel Bawah Laut dari Laut ke Darat

b. Beach Manhole (BMH)

$\mathrm{BMH}$ merupakan instalasi penunjang jaringan kabel yang dipasang di bawah permukaan tanah. Instalasi ini berfungsi untuk mengontrol koneksi antara kabel laut dengan kabel darat. 
c. Power House (PH), merupakan tempat instalasi kontrol listrik agar sistem deteksi dini tsunami dapat terus berjalan.

d. Tower Komunikasi, merupakan infrastruktur untuk menangkap dan mengirimkan sinyal komunikasi agar data sistem deteksi dini tsunami dapat terkirim ke pusat data.

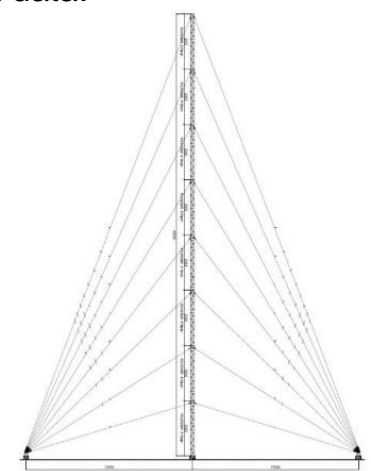

Gambar 3. Contoh llustrasi Menata Segitiga pada Sistem Deteksi Dini Tsunami

(Sumber: Pradono, 2020)

\subsubsection{Luas Lahan}

Luas lahan yang dibutuhkan dibagi menjadi tiga kategori berdasarkan kelompok komponen lahan yang ada, yaitu sebagai berikut:

a. Kategori A

Lahan ini hanya terdiri dari instalasi $\mathrm{BMH}$ saja dengan luas lahan yang dibutuhkan adalah $4 \mathrm{~m} \times 8 \mathrm{~m}$.

b. Kategori $B$

Lahan kategori B terdiri dari $\mathrm{PH}$ dan tower yang berada di satu kawasan. Luas lahan yang dibutuhkan untuk kategori ini adalah $10 \mathrm{~m} \times 12 \mathrm{~m}$.

c. Kategori $\mathrm{C}$

Kategori $\mathrm{C}$ terdiri dari tiga komponen, yaitu $\mathrm{BMH}, \mathrm{PH}$, dan tower dengan luas lahan yang dibutuhkan adalah $10 \mathrm{~m} \times 16$ $\mathrm{m}$.

Kategorisasi ini dibuat karena menyesuaikan dengan ketersediaan lahan yang ada dan desain infrastruktur yang akan dibangun. BMH dapat diletakkan bersamaan dengan $\mathrm{PH}$ dan tower atau dapat diletakkan terpisah, sehingga kategorisasi luas lahan dibuat.

\subsection{Metode}

Kriteria pemilihan lokasi landing station mengacu pada ICPC Recommendation No. 9 (ICPC, 2018) yang dimodifikasi dan disesuaikan dengan keadaan yang terjadi di Indonesia dan kriteria desain infrastruktur yang akan dibangun. Kriteria untuk setiap komponen lahan di atas antara lain sebagai berikut:

1. Relatif aman terhadap dampak tsunami (khususnya untuk lokasi PH).

2. Kondisi tanah kuat dan stabil.

3. Kondisi tanah relatif datar.

4. Bebas dari tanah longsor.

5. Kepemilikan lahan yang jelas.

6. Untuk bangunan PH dan tower berada pada jarak minimal 100 meter dari garis pantai (di luar area sempadan pantai).

7. Terjangkau oleh jaringan komunikasi dan internet yang kuat.

8. Tidak terganggu oleh pohon dan vegetasi yang tinggi.

9. Terdapat suplai tenaga listrik.

10. Lajur rencana kabel tidak memotong sungai atau jalan raya utama.

11. Mudah diakses untuk kendaraan berat saat proses konstruksi.

12. Diterima dan disetujui oleh instansi ataupun masyarakat sekitar.

Kriteria tersebut yang diringkas ke dalam aspek dan parameter kemudian akan dinilai dengan metode skoring. Metode skoring digunakan karena setiap parameter memiliki nilai dengan rentang tertentu.

Pada metode skoring yang digunakan, setiap aspek memiliki bobot yang sama yaitu $20 \%$. Selain itu, skor 1 diberikan untuk parameter yang tidak memenuhi kriteria dan skor 2 diberikan untuk parameter yang memenuhi kriteria yang diharapkan.

\subsection{Pengumpulan Data}

Data diperoleh berdasarkan informasi yang didapat secara langsung dari lapangan serta berupa data sekunder. Beberapa data yang diperoleh dikategorikan menjadi 5 aspek yang dimodifikasi dari ICPC Recommendation No. 9 seperti pada Tabel 2 berikut. 
Puspa Khaerani, Heru Sri Naryanto, Dian Nuraini Melati, Syakira Trisnafiah: Kajian Landing Station Alat Deteksi Dini Tsunami Berbasis Kabel Serat Optik Bawah Laut Di Kabupaten Pasangkayu,

Sulawesi Barat

Tabel 2. Kategori Pengumpulan Data Hasil Modifikasi ICPC Recommendation No. 9 Tahun 2018

\begin{tabular}{|c|c|c|}
\hline Aspek & Deskripsi & Sumber Data \\
\hline Deskripsi Area & $\begin{array}{l}\text { 1. Titik Rencana LP, BMH, } \mathrm{PH} \text {, dan tower } \\
\text { 2. Layout jalur rencana kabel dari LP ke tower } \\
\text { 3. Jenis tanah pada tiap komponen lokasi } \\
\text { 4. Estimasi kemiringan atau profil lahan } \\
\text { 5. Hambatan yang mungkin ada }\end{array}$ & $\begin{array}{ll}\text { 1. } & \text { Observasi } \\
\text { 2. Observasi dan desktop } \\
\text { 3. Observasi } \\
\text { 4. Observasi } \\
\text { 5. Data sekunder dan wawancara }\end{array}$ \\
\hline Kondisi Lingkungan & $\begin{array}{l}\text { 1. Lokasi terumbu karang, kawasan lindung, } \\
\text { atau area bakau } \\
\text { 2. Area perlindungan ikan } \\
\text { 3. Area migrasi mamalia laut } \\
\text { 4. Potensi erosi pantai di sekitar LP dan BMH } \\
\text { 5. Kondisi cuaca, pasang surut, dan area } \\
\text { selancar }\end{array}$ & $\begin{array}{l}\text { 1. Data sekunder dan observasi } \\
\text { 2. Data sekunder dan observasi } \\
\text { 3. Data sekunder dan observasi } \\
\text { 4. Observasi } \\
\text { 5. Observasi }\end{array}$ \\
\hline $\begin{array}{l}\text { Infrastruktur } \\
\text { Pendukung }\end{array}$ & $\begin{array}{l}\text { 1. Akses menuju lokasi } \\
\text { 2. Kebutuhan peningkatan akses jalan } \\
\text { 3. Transportasi menuju lokasi untuk personil } \\
\text { dan peralatan } \\
\text { 4. Fasilitas komunikasi }\end{array}$ & $\begin{array}{ll}\text { 1. } & \text { Observasi } \\
\text { 2. } & \text { Observasi } \\
\text { 3. } & \text { Observasi } \\
\text { 4. } & \text { Observasi } \\
\end{array}$ \\
\hline $\begin{array}{l}\text { Faktor Sosial dan } \\
\text { Perizinan }\end{array}$ & $\begin{array}{l}\text { 1. Rencana Tata Ruang, pengembangan, } \\
\text { ataupun pembangunan di sekitar lokasi } \\
\text { 2. Kepemilikan lahan } \\
\text { 3. Ketersediaan penggunaan lahan } \\
\text { 4. Aktivitas kebudayaan atau adat }\end{array}$ & $\begin{array}{l}\text { 1. Observasi dan wawancara } \\
\text { 2. Observasi dan wawancara } \\
\text { 3. Wawancara } \\
\text { 4. Wawancara } \\
\end{array}$ \\
\hline Aktivitas Laut & $\begin{array}{l}\text { 1. Lokasi pelabuhan atau dermaga terdekat } \\
\text { 2. Jalur lalu lintas laut } \\
\text { 3. Lokasi labuh jangkar di sekitar } \\
\text { 4. Aktivitas penangkapan ikan } \\
\text { 5. Kemungkinan kegiatan pengerukan }\end{array}$ & $\begin{array}{ll}\text { 1. } & \text { Observasi dan data sekunder } \\
\text { 2. Data sekunder } \\
\text { 3. Data sekunder } \\
\text { 4. Observasi dan data sekunder } \\
\text { 5. Observasi dan data sekunder }\end{array}$ \\
\hline
\end{tabular}

\section{HASIL DAN PEMBAHASAN}

\subsection{Kajian Landing Station dan Landing Point di Kabupaten Pasangkayu}

Dari hasil desktop study, didapatkan 3 lokasi alternatif landing station. Alternatif lokasi yang dicari utamanya adalah lokasi yang sesuai dengan kriteria pendaratan kabel dimana terdapat suplai energi yang dapat dilihat dari ada atu tidaknya pemukiman di sekitar serta daerah dengan ketersediaan lahan yang ada dan dekat dengan pusat pemerintahan daerah baik tingkat desa atau kecamatan, kabupaten atau kota, maupun provinsi. Gambaran posisi untuk setiap alternatif lokasi dapat dilihat pada Gambar 4 dan rincian keterangan lokasi dapat dilihat pada Tabel 3.

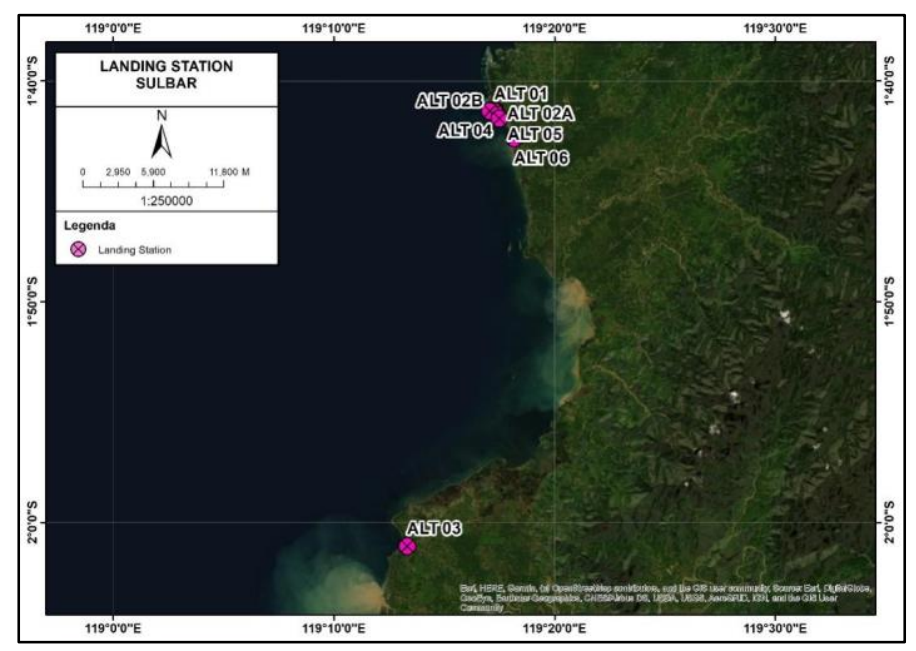

Gambar 4. Lokasi Alternatif Landing Station (Sumber: Hasil Analisis, 2021) 
Puspa Khaerani, Heru Sri Naryanto, Dian Nuraini Melati, Syakira Trisnafiah: Kajian Landing Station Alat Deteksi Dini Tsunami Berbasis Kabel Serat Optik Bawah Laut Di Kabupaten Pasangkayu,

Sulawesi Barat

Tabel 3. Koordinat Alternatif Landing Station Sulawesi Barat

\begin{tabular}{|c|c|c|c|}
\hline Alternatif & Wilayah & Lintang & Bujur \\
\hline ALT 01 & $\begin{array}{l}\text { Sarudu, Kecamatan Sarudu, Kabupaten } \\
\text { Pasangkayu, Provinsi Sulawesi Barat }\end{array}$ & $1^{\circ} 41^{\prime} 24,036 "$ LS & $119^{\circ} 17^{\prime} 15,972 " \mathrm{BT}$ \\
\hline ALT 02A & $\begin{array}{l}\text { Sarudu, Kecamatan Sarudu, Kabupaten } \\
\text { Pasangkayu, Provinsi Sulawesi Barat }\end{array}$ & $1^{\circ} 41^{\prime} 20,076 "$ LS & $119^{\circ} 17^{\prime} 18,312^{\prime \prime}$ BT \\
\hline ALT 02B & $\begin{array}{l}\text { Sarudu, Kecamatan Sarudu, Kabupaten } \\
\text { Pasangkayu, Provinsi Sulawesi Barat }\end{array}$ & $1^{\circ} 41^{\prime} 22,200 "$ LS & $119^{\circ} 17^{\prime} 15,540 "$ BT \\
\hline ALT 03 & $\begin{array}{l}\text { Tumbu, Kecamatan Topoyo, Kabupaten } \\
\text { Mamuju Tengah, Provinsi Sulawesi Barat }\end{array}$ & $2^{\circ} 01^{\prime} 04,836 "$ LS & $119^{\circ} 13^{\prime} 18,948 "$ BT \\
\hline ALT 04 & $\begin{array}{l}\text { Sarudu, Kecamatan Sarudu, Kabupaten } \\
\text { Pasangkayu, Provinsi Sulawesi Barat }\end{array}$ & $1^{\circ} 41^{\prime} 22,236 "$ LS & $119^{\circ} 17^{\prime} 03,660^{\prime \prime} \mathrm{BT}$ \\
\hline ALT 05 & $\begin{array}{l}\text { Sarudu, Kecamatan Sarudu, Kabupaten } \\
\text { Pasangkayu, Provinsi Sulawesi Barat }\end{array}$ & $1^{\circ} 41^{\prime} 42,252 "$ LS & $119^{\circ} 17^{\prime} 29,760^{\prime \prime}$ BT \\
\hline ALT 06 & $\begin{array}{l}\text { Sarudu, Kecamatan Sarudu, Kabupaten } \\
\text { Pasangkayu. Provinsi Sulawesi Barat }\end{array}$ & $1^{\circ} 42^{\prime} 36,504^{\prime \prime}$ LS & $119^{\circ} 18^{\prime} 10,188^{\prime \prime} \mathrm{BT}$ \\
\hline
\end{tabular}

\subsection{Lokasi Landing Station Terpilih}

Pada bagian ini akan dijelaskan mengenai kondisi di lokasi landing station terpilih. Gambaran lokasi terpilih dijelaskan sebagai berikut.

\subsubsection{Gambaran Umum}

Dari hasil site visit, didapatkan lahan ALT02B untuk posisi $\mathrm{PH}$ dan tower pada koordinat $1^{\circ} 41^{\prime}$ 22,200" LS dan $119^{\circ} 17^{\prime} 15,540 "$ BT tepatnya pada Barat Daya tower BTS kembar, Kecamatan Sarudu, Kabupaten Pasangkayu. Elevasi sebesar 27,8 meter di atas permukaan air laut berdasarkan data elevasi DEMNAS. Jarak lokasi alternatif dari garis pantai adalah sejauh 353 meter. Tingkat kepadatan penduduk di lokasi ini terbilang cukup rendah. Jaringan listrik di lokasi terpilih sudah tersedia dengan daya yang digunakan warga sekitar 900 - 1300 Watt. Sinyal telekomunikasi di lokasi ini juga cukup baik. Gambaran lokasi ALT-02B dapat dilihat pada gambar di bawah ini.

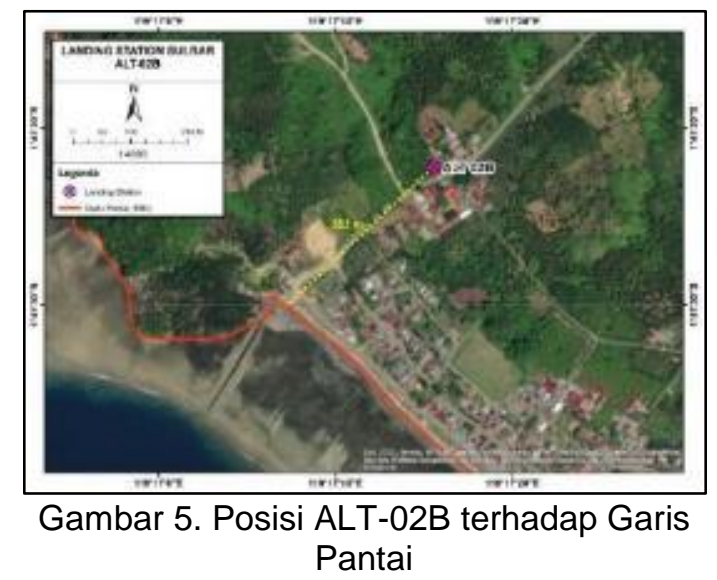

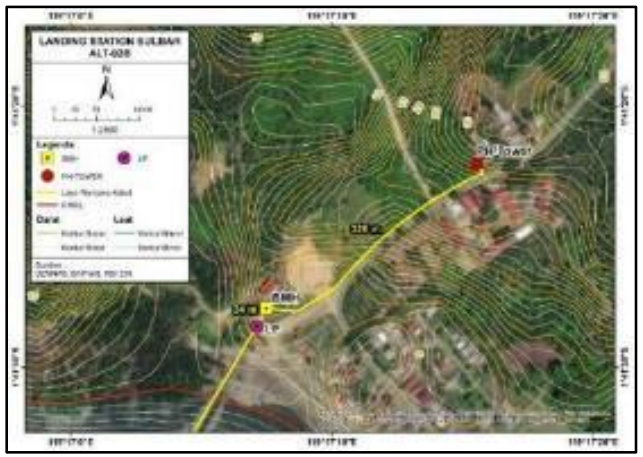

Gambar 6. Lokasi ALT-02B Sulbar

Berdasarkan jalur rencana kabel darat di atas, berikut adalah tampilan untuk profil memanjang dari topografinya berdasarkan data dari DEMNAS.

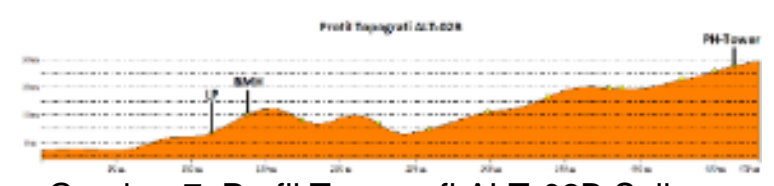

Gambar 7. Profil Topografi ALT-02B Sulbar

Lokasi ALT-02B Sulbar berada di area barat daya BTS kembar. Jarak lajur kabel dari lokasi rencana $\mathrm{PH}$-tower ke BMH sekitar 326 meter mengikuti jalur jalan desa beraspal dan jalan lintas Sulawesi dari lokasi BMH ke $\mathrm{PH}-$ tower tersebut. Sementara itu, untuk jarak dari LP ke BMH adalah sejauh 24 meter.

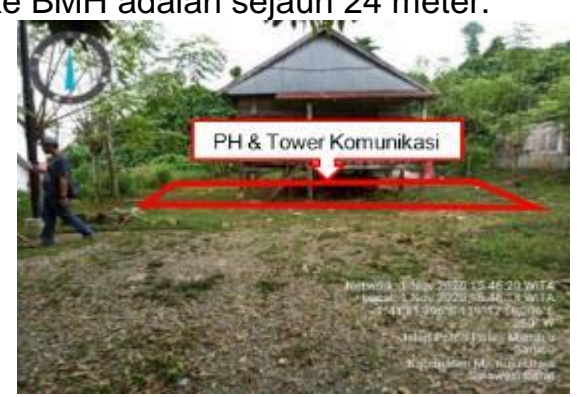

Gambar 8. Gambaran Lokasi PH-Tower ALT-02B Sulawesi Barat 


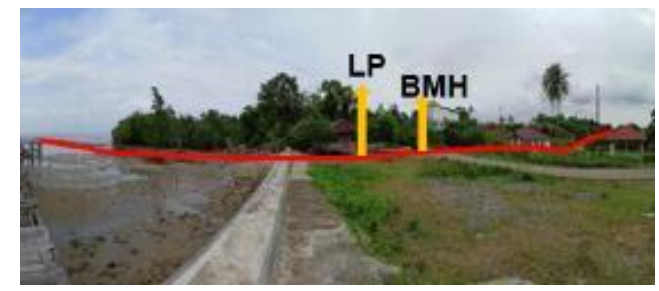

Gambar 9. Gambaran Lokasi LP dan BMH ALT-02B Sulawesi Barat

\subsubsection{Deskripsi Power House (PH) dan Tower}

Area rencana berada di sebelah barat daya tower BTS kembar, Kecamatan Sarudu, Kabupaten Pasangkayu pada koordinat $1^{\circ} 41^{\prime}$ 22.200" LS dan $119^{\circ} 17^{\prime} 15.540^{\prime \prime}$ BT dengan elevasi sebesar 27,8 meter di atas permukaan air laut berdasarkan data elevasi DEMNAS. Di area ini terdapat lahan berupa bangunan tidak permanen yang memungkinkan untuk dapat digunakan sebagai lahan untuk $\mathrm{PH}$ dan tower. Gambaran untuk lokasi PH dan tower ALT02B dapat dilihat pada gambar di bawah ini.

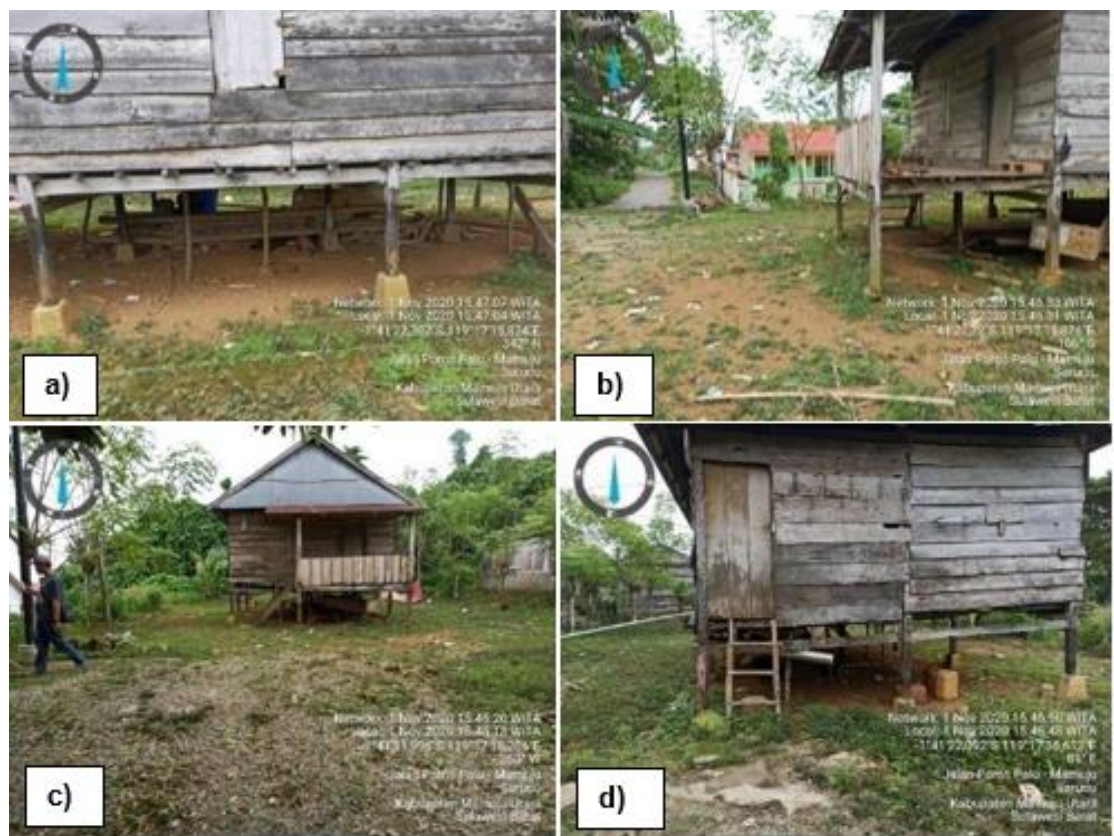

Gambar 10. Kenampakan Lokasi Rencana PH-Tower ALT-02B Sulawesi Barat dari arah a) Utara, b) Selatan, c) Barat, d) Timur

Lahan ini merupakan lahan milik warga dimana terdapat bangunan semi permanen di dalam lahan tersebut. Akses jalan menuju lokasi ini berupa jalan lintas Sulawesi (Palu Mamuju). Akses rencana kabel menuju lokasi ini akan memotong jalan menuju pelabuhan PT. Astra yang masih berupa jalan tanah berkerikil.

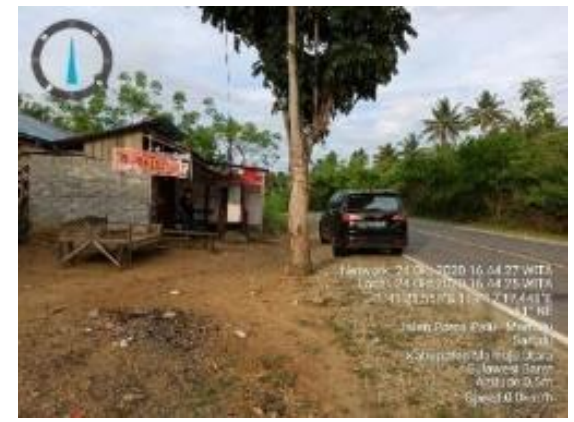

Gambar 11. Akses Jalan Menuju Lokasi PHTower ALT-02B Sulawesi Barat

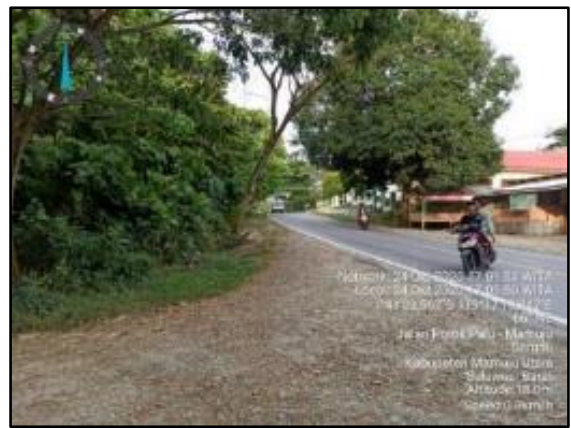

Gambar 12. Jalan Tanah Berkerikil yang akan Dilewati Rencana Kabel

\subsubsection{Deskripsi $B M H$}

Lokasi rencana BMH ALT-02B berupa semak dan ada sedikit pohon sawit dengan koordinat $1^{\circ} 41^{\prime} 27.744^{\prime \prime}$ LS dan $119^{\circ} 17^{\prime}$ 7.476" BT yaitu di samping jalan aspa menuju pantai. Elevasi sebesar 10 meter di atas permukaan air laut (data DEMNAS). Jenis 
tanah di lokasi ini berupa lempung pasiran. Hambatan yang mungkin timbul di lokasi ini adalah Muka Air Tanah (MAT) di sekitar yaitu $0,5 \mathrm{~m}-1,0 \mathrm{~m}$ saat musim hujan sehingga konstruksi $\mathrm{BMH}$ harus disesuaikan. Lokasi rencana $\mathrm{BMH}$ adalah lahan milik warga status lahan yaitu berupa tanah sporadik. Akses untuk menuju lokasi rencana BMH ALT-02B dapat ditempuh melalui jalan lintas Sulawesi. Gambaran area lokasi BMH dapat dilihat pada gambar di bawah ini.
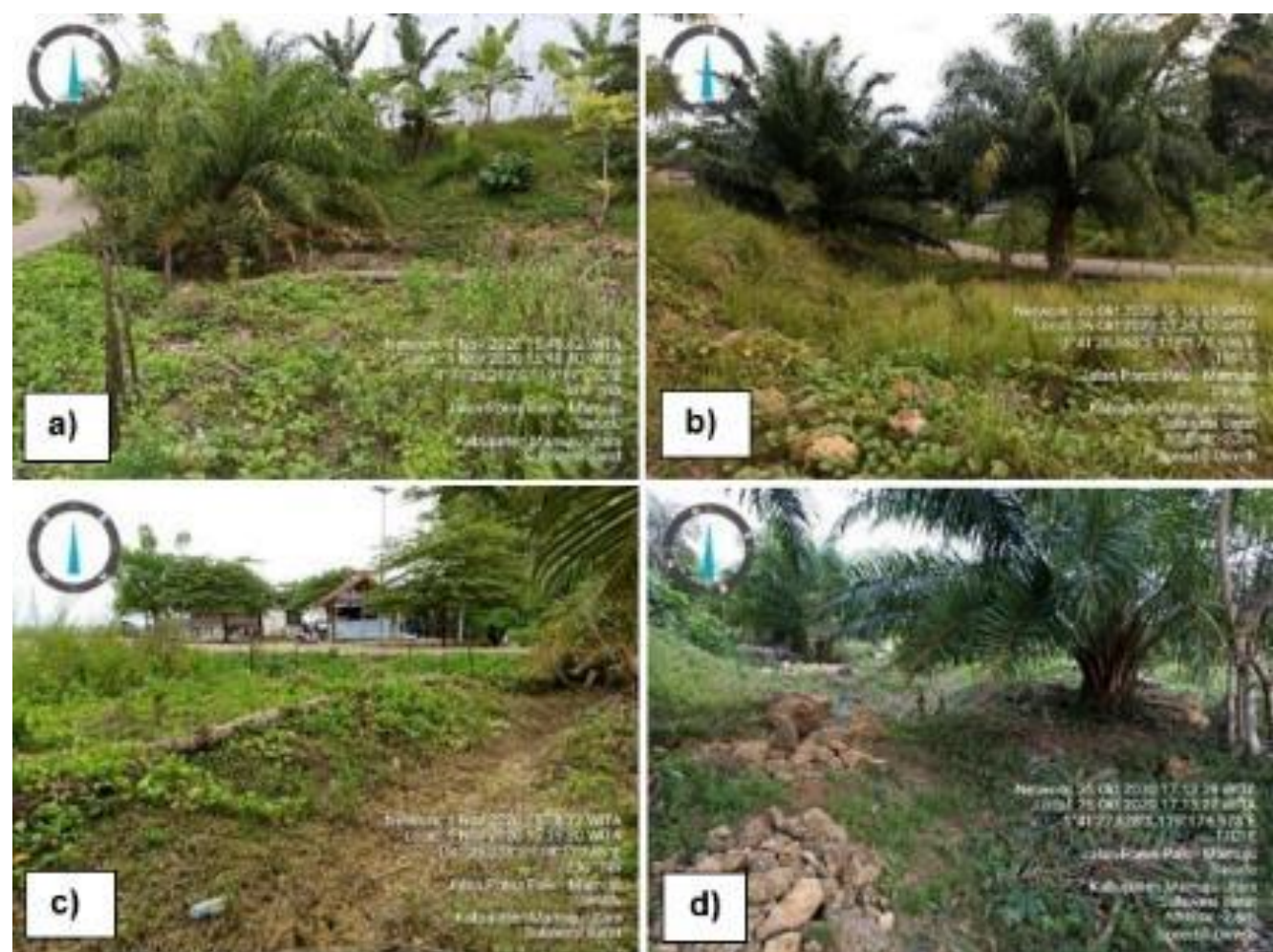

b)

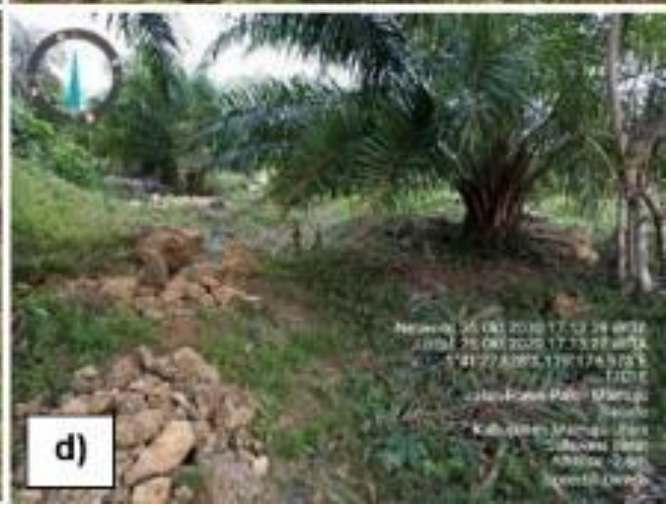

Gambar 13. Kenampakan Lokasi BMH ALT-02B Sulawesi Barat dari arah a) Utara, b) Selatan, c) Barat, d) Timur

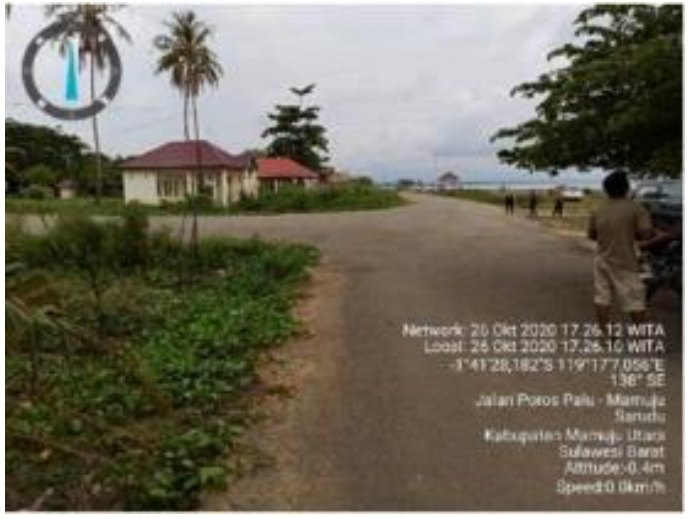

Gambar 14. Akses Jalan Sekitar BMH ALT02B Sulawesi Barat

\subsubsection{Deskripsi Landing Point (LP)}

Lokasi rencana LP ALT-02B berada di area Pantai Cinoki, Sarudu dengan koordinat $1^{\circ} 41^{\prime}$ 28.428" LS dan 119 ${ }^{\circ} 17^{\prime} 7.116^{\prime \prime}$ BT. Jenis tanah pada pesisir pantai ini berupa tanah pasiran. Pantai ini menjadi lokasi yang cocok untuk lokasi landing point salah satunya dikarenakan pantai ini merupakan pantai wisata yang sudah tidak aktif. Selain itu, tingkat erosi di wilayah pantai juga cukup kecil. Di sekitar lokasi LP area terumbu karang, bakau, batu karang maupun area sensitive lainnya berada di sebelah utara lokasi LP. Namun, lokasi-lokasi tersebut tidak perlu dikhawatirkan karena jalur kabel serat optik bawah laut yang direncanakan tidak melewati area tersebut.

Aktivitas nelayan di lokasi ini juga minim, tidak ada kegiatan budidaya perikanan di depan lokasi LP yang direncanakan. Selain itu juga tidak ada surfing zone sehingga dapat dibilang cukup aman. .Namun di lokasi ini terdapat retaining wall sehingga pada saat pendaratan kabel harus memperhatikan hal tersebut. Gambaran area lokasi LP dapat dilihat pada gambar di bawah ini. 


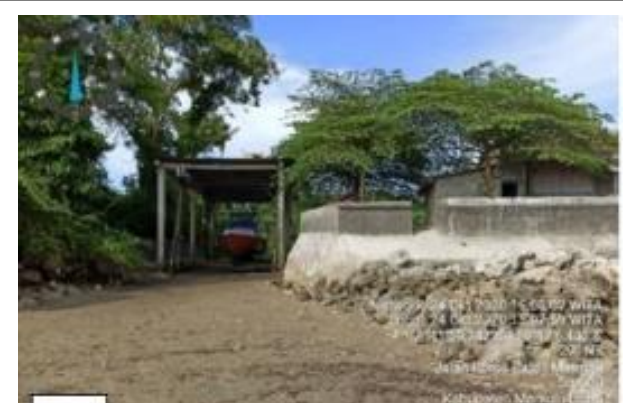

a)

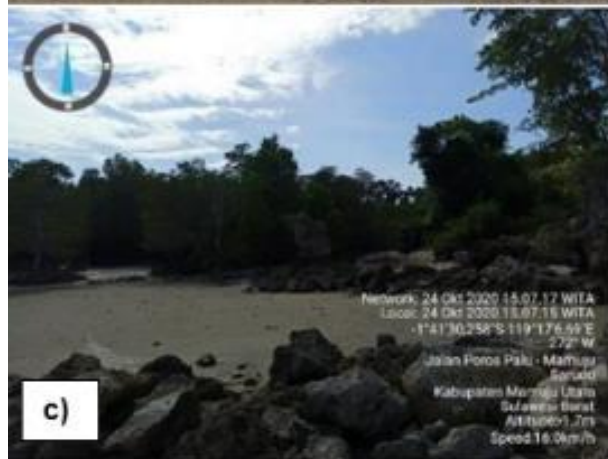

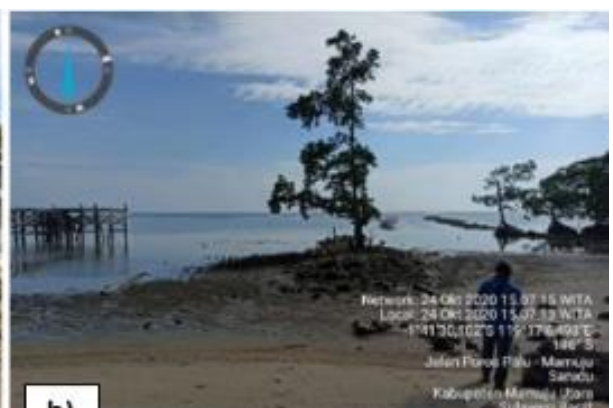

b)

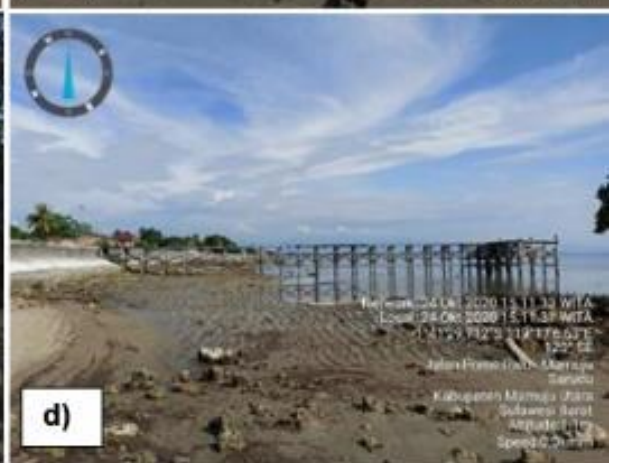

Gambar 15. Kenampakan Lokasi LP ALT-02B Sulawesi Barat dari arah a) Utara, b) Selatan, c) Barat, d) Timur

Area LP merupakan tanah kosong bersemak dekat parit dan beberapa pohon sawit dengan permukaan tanah yang datar, dan laut di depan LP tidak ada aktivitas sandar/tambat kapal nelayan. Akses untuk menuju lokasi rencana LP ALT-02B dapat ditempuh melalui jalan aspal dekat pantai.

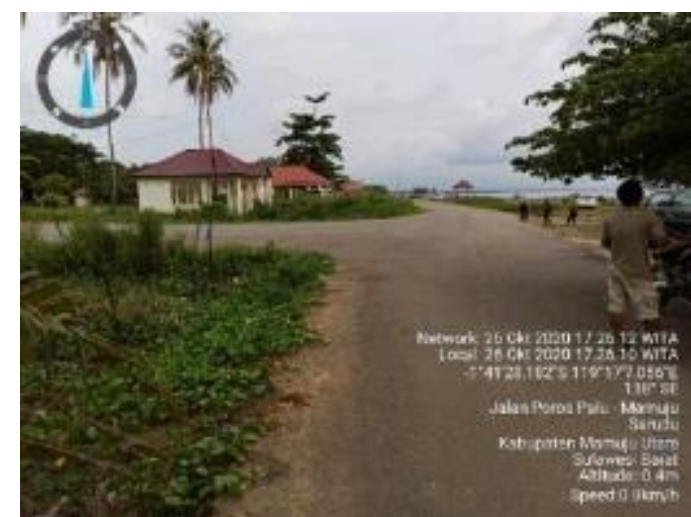

Gambar 16. Akses Jalan Sekitar LP ALT-02B Sulawesi Barat

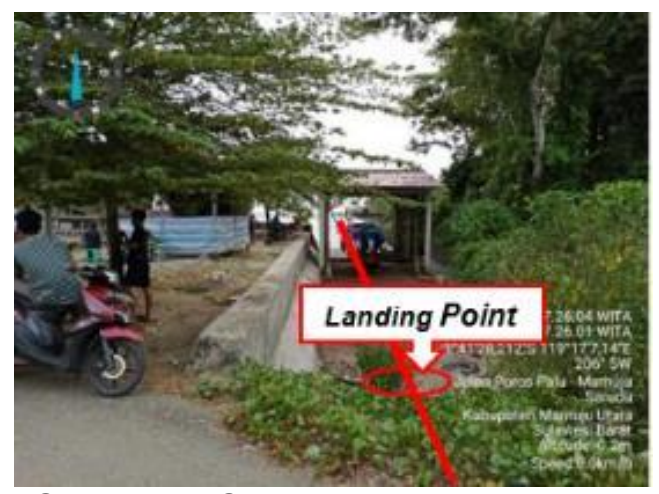

Gambar17. Gambaran Rencana Lokasi Landing Point ALT-02B Sulawesi Barat

\subsubsection{Kondisi Lingkungan}

Terdapat karang dan hutan bakau di sekitar area pantai, namun LP tidak melewati objek tersebut (terdapat jalur yang sudah dikeruk yang dapat digunakan sebagai jalur dari kabel laut menuju LP). Aktivitas nelayan di sekitar lokasi minim dan tidak ada ada kegiatan budidaya perikanan. Rencana tata ruang di sekitar lokasi berupa pengembangan industri sawit yang kini sudah ada dan tidak ada rencana pengembangan yang signifikan di lokasi tersebut.

Berikut posisi ALT-02B terhadap Peraturan Daerah Kabupaten Mamuju Utara (Kabupaten Pasangkayu) No. 1 tahun 2014 tentang RTRW Kabupaten Mamuju Utara (Pasangkayu) tahun 2014 - 2034. Berdasarkan informasi ini, lokasi $\mathrm{PH}$-tower, BMH, dan LP sama-sama berada di area kawasan permukiman pedesaan. Dari 
data Badan Informasi Geospasial (BIG), diketahui bahwa kondisi pasang surut di lokasi ini memiliki tunggang pasang surut sekitar 2,4 meter dengan tipe pasang surut campuran condong ke harian tunggal.

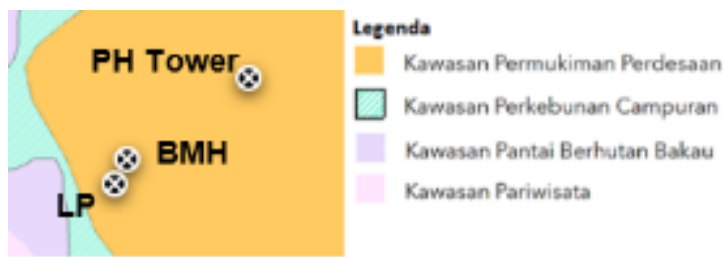

Gambar 18. Lokasi ALT-02B terhadap Rencana Tata Ruang Wilayah Kabupaten Pasangkayu 2014-2034

\subsubsection{Faktor Sosial dan Perizinan}

Area rencana PH-tower ALT-02B adalah lahan milik warga. Lahan yang berupa bangunan semi permanen diizinkan untuk dibongkar. Area rencana BMH ALT-02B juga merupakan lahan milik masyarakat sekitar. Sementara untuk area sekitar LP lahan milik Desa Sarudu. Perizinan lokasi LP dapat dilakukan melalui koordinasi dengan perangkat Desa Sarudu. Namun, untuk lokasi $\mathrm{PH}$ dan tower dibutuhkan pendekatan khusus jika lahan tersebut jadi digunakan karena merupakan lahan milik masyarakat sekitar walaupun masyarakat sudah setuju bahwa lahannya dapat digunakan untuk pembangunan infrastruktur darat sistem deteksi dini tsunami. Namun, perlu diantisipasi peraturan yang berlaku dan hal-hal yang dapat dilakukan dan tidak dilakukan dalam pemrosesan pembangunan infrastruktur di lahan milik masyarakat terutama memperhatikan kearifan lokal masyarakat.

\subsubsection{Aktivitas Laut dan Fasilitas Pendukung}

Aktivitas nelayan di sekitar area LP pada lokasi alternatif ini tidak ada. Lokasi ALT-02B berjarak sekitar $5,7 \mathrm{~km}$ dari Pelabuhan Bone Manjing. Akses menuju lokasi dapat ditempuh menggunakan jalan raya utama (Lintas Sulawesi Palu-Mamuju) dengan kondisi jalan yang baik. Pelabuhan ini berfungsi untuk bongkar muat kapal pembawa sawit (CPO). Di dekatnya, terdapat pelabuhan logistik dengan panjang dermaga sekitar $50 \mathrm{~m}$ yang berfungsi untuk bongkar muat kapal-kapal masyarakat yang membawa sembako,sayuran dan buahan dan di kirim ke Kalimantan.

Untuk bandara, terdapat dua alternatif yang dapat ditempuh. Yang pertama adalah Bandar Udara Tampa Padang di Mamuju dengan jarak sekitar $200 \mathrm{~km}$ yang dapat ditempuh melalui jalur darat yang banyak kelokan dan naik turun. Alternatif kedua, Bandar Udara Mutiara SIS AL Jufrie di Palu dengan jarak sekitar 216 $\mathrm{km}$.

\subsection{Penilaian Lokasi Alternatif Landing Station}

Penilaian lokasi alternatif landing station menggunakan sistem bobot dan skoring terhadap parameter yang menjadi acuan pemilihan lokasi. Penilaian ini dilakukan oleh surveyor yang diperiksa kembali oleh tim manajemen, teknis, perizinan, dan surveyor secara bersama-sama untuk mendapatkan keputusan. Terdapat lima aspek yang menjadi acuan dalam penilaian lokasi landing station dan total 10 parameter yang dilihat melalui observasi lapangan langsung maupaun melalui data sekunder. Aspek yang digunakan dianggap memiliki bobot yang sama karena setiap aspek tersebut harus dipertimbangkan walaupun pada beberapa kasus ada hal-hal yang harus dikorbankan dan diusahakan lebih dalam pemilihan Setiap parameter diberikan skor atau nilai 1 jika tidak memenuhi kriteria yang diharapkan dan diberikan nilai 2 jika memenuhi kriteria yang diharapkan. Penilaian masing-masing parameter untuk setiap lokasi alternatif landing station dapat dilihat pada Tabel 4.

Tabel 4. Penilaian Lokasi Alternatif Landing Station di Sulawesi Barat

\begin{tabular}{|c|c|c|c|c|c|c|c|c|c|}
\hline \multirow{2}{*}{ Aspek } & \multirow{2}{*}{ Parameter } & \multirow{2}{*}{ Bobot } & \multicolumn{7}{|c|}{ Alternatif Lokasi (ALT-) } \\
\hline & & & 01 & 02A & 02B & 03 & 04 & 05 & 06 \\
\hline \multirow[t]{4}{*}{ Deskripsi Area } & Ketersediaan lahan & 20 & 1 & 1 & 2 & 2 & 2 & 2 & 2 \\
\hline & $\begin{array}{l}\text { Elevasi aman terhadap } \\
\text { Tsunami }\end{array}$ & & 2 & 2 & 2 & 1 & 1 & 1 & 1 \\
\hline & Stabilitas tanah & & 1 & 2 & 2 & 1 & 2 & 2 & 2 \\
\hline & Jarak dari pantai & & 2 & 2 & 2 & 2 & 2 & 2 & 1 \\
\hline Kondisi Lingkungan & Kondisi lingkungan sekitar & 20 & 2 & 2 & 2 & 2 & 1 & 2 & 1 \\
\hline Infrastruktur & Rute kabel tidak memotong & 20 & 2 & 2 & 2 & 2 & 2 & 2 & 2 \\
\hline
\end{tabular}




\begin{abstract}
Pendukung
sungai atau jalan raya

Kondisi sinyal GSM

Jaringan listrik

Faktor Sosial dan Kondisi sosial masyarakat

Perizinan

Aktivitas Laut

Aman dari hambatan lain

TOTAL

Keterangan:

Skor 1 : Tidak memenuhi kriteria

Skor 2 : Memenuhi kriteria

Jika dilihat pada Tabel 4, setiap aspek penilaian memiliki bobot yang sama yaitu $20 \%$. Hal ini dikarenakan pada saat pemilihan lokasi, setiap aspek dianggap memilliki pertimbangan yang setara dan dianggap sama pentingnya dalam pemilihan lokasi landing station.

Berdasarkan tabel aspek penilaian setiap lokasi tersebut, nilai total menunjukkan perkalian antara skor setiap parameter di setiap lokasi dengan bobot aspek penilaian. Sehingga, urutan lokasi alternatif yang memiliki prospek paling tinggi untuk dipilih menjadi calon lokasi landing station didasarkan pada nilai total. Tiga nilai total tertinggi adalah 400, 380, dan 340 yang secara berurutan menunjukkan lokasi ALT02B, ALT-02A, dan ALT-06. Sehingga, berdasarkan nilai total dan penjelasan lokasi terpilih yang sudah dibahas sebelumnya alternatif yang besar kemungkinan dipilih menjadi lokasi landing station adalah lokasi alternatif 02B.
\end{abstract}

\section{KESIMPULAN DAN SARAN}

Kesimpulan yang didapat dari hasil kegiatan observasi lapangan maupun analisis data sekunder lokasi alternatif landing station sistem deteksi dini tsunami berbasis kabel serat optik bawah laut atau InaCBT di Kabupaten Pasangkayu, Sulawesi Barat adalah lokasi ALT-02 yang berada di sekitar area tower BTS kembar. Pada ALT-02 terdapat dua alternatif lokasi untuk digunakan sebagai lahan $\mathrm{PH}$-tower. Rekomendasi alternatif lokasi secara berurutan dengan nilai total 400, 380, dan 340 adalah ALT-02B, ALT02A, dan ALT-06.

Pemilihan lokasi alternatif ini tidak menutup kemungkinan berubahnya lokasi terpilih yang akan digunakan pada saat pembangunan infrastruktur darat sistem deteksi dini tsunami. Hal ini dikarenakan masih banyak faktor yang harus dipertambangkan. Selain itu, diantara aspek parameter yang dianalisis di atas harus ada prioritas parameter yang menjadi penentu dalam pemilihan lokasi landing station dikarenakan dalam pemilihan lokasi pembangunan pasti ada hal-hal yang harus dilakukan dan hal-hal yang dapat diminimalisir untuk menghindari dampak dan risiko lain yang mungkin timbul.

\section{PERSANTUNAN}

Penulis mengucapkan terima kasih kepada Direktur PTRRB Tahun 2020 karena atas dukungannya observasi lapangan dan kajian ini dapat dilakukan.

\section{DAFTAR PUSTAKA}

Bachri, S. 2012. Fase Kompresi Di Selat Makassar Berdasarkan Data Geologi Daratan, Seismik Laut dan Citra Satelit. Jurnal Sumber Daya Geologi, 22(3): 13744.

Bernard, E. and V. Titov. 2015. Evolution of tsunami warning systems and products. Phil. Trans. R. Soc. A 373: 20140371, http://dx.doi.org/10.1098/rsta.2014.0371

Brackenridge, R, U. Nicholson, B. Sapiie, D. Stow \& D. R. Tappin. 2019. Indonesian Throughflow as a preconditioning mechanism for submarine landslides in the Makassar Strait. Geological Society, London, Special Publications. DOI: https://doi.org/10.1144/SP500-2019-171.

ICPC. 2018. International Cable Protection Committee (ICPC) Recommendation No. 9 about Minimum Technical Requirements for a Desktop Study. England: ICPC Ltd.

Muhari, A., F. Imamura, T. Arikawa, A. R. Hakim, and B. Afriyanto. Solving the Puzzle of the September 2018 Palu, Indonesia, Tsunami Mystery: Clues from the Tsunami Waveform and the Initial Field Survey Data. Journal of Disaster Research, 13, Scientific Communication Online, 1-3.

Nakata, K., A. Katsumata, and A. Muhari. 2020. ubmarine landslide source models consistent with multiple tsunami records of the 2018 Palu tsunami, Sulawesi, Indonesia. Earth, Planets and Space, 
Puspa Khaerani, Heru Sri Naryanto, Dian Nuraini Melati, Syakira Trisnafiah: Kajian Landing Station Alat Deteksi Dini Tsunami Berbasis Kabel Serat Optik Bawah Laut Di Kabupaten Pasangkayu,

\footnotetext{
72(44):

https://doi.org/10.1186/s40623-020-

$1-16$

01169-3

National Geophysical Data Center / World

Data Service: NCEI/WDS Global

Historical Tsunami Database. NOAA

National Centers for Environmental Information. doi:10.7289/V5PN93H7

Pradono, M. H. 2020. Kajian Kerentanan

Fasilitas Darat InaCBT Terhadap

Guncangan Gempabumi. Jurnal Alami, 4(1): 28-40.

PUPR. 2017. Buku Peta Gempa 2017.
} 